\title{
Free Amino Acid and Volatile Compound Profiles of Jeotgal Alternatives and Its Application to Kimchi
}

\author{
Hye Jin Lee ${ }^{1}$, Min Jung Lee ${ }^{1}$, Yun-Jeong Choi ${ }^{1}$, Sung Jin Park ${ }^{1}$, Mi-Ai Lee ${ }^{1}$, Sung Gi Min ${ }^{1}$, Sung-Hee Park ${ }^{1}$, \\ Hye-Young Seo ${ }^{2}$ and Ye-Rang Yun ${ }^{1, *(1)}$ \\ 1 Industrial Technology Research Group, World Institute of Kimchi, Gwangju 61755, Korea \\ hj10617@wikim.re.kr (H.J.L.); leemj@wikim.re.kr (M.J.L.); yjchoi85@wikim.re.kr (Y.-J.C.); \\ parksungjin@wikim.re.kr (S.J.P.); leemae@wikim.re.kr (M.-A.L.); skmin@wikim.re.kr (S.G.M.); \\ shpark@wikim.re.kr (S.-H.P.) \\ 2 Hygienic Safety and Analysis Center, World Institute of Kimchi, Gwangju 61755, Korea; hyseo@wikim.re.kr \\ * Correspondence: yunyerang@wikim.re.kr; Tel.: +82-626-101-849; Fax: +82-626-101-850
}

check for updates

Citation: Lee, H.J.; Lee, M.J.; Choi, Y.-J.; Park, S.J.; Lee, M.-A.; Min, S.G.; Park, S.-H.; Seo, H.-Y.; Yun, Y.-R. Free Amino Acid and Volatile Compound Profiles of Jeotgal Alternatives and Its Application to Kimchi. Foods 2021, 10, 423. https://doi.org/10.3390/foods 10020423

Academic Editor:

Remedios Castro-Mejías

Received: 11 January 2021

Accepted: 12 February 2021

Published: 15 February 2021

Publisher's Note: MDPI stays neutral with regard to jurisdictional claims in published maps and institutional affiliations.

Copyright: (c) 2021 by the authors. Licensee MDPI, Basel, Switzerland. This article is an open access article distributed under the terms and conditions of the Creative Commons Attribution (CC BY) license (https:// creativecommons.org/licenses/by/ $4.0 /)$.

\begin{abstract}
Jeotgal containing abundant free amino acids plays an important role in the unique savory taste (umami) and flavor in kimchi. However, it is also responsible for the unpleasant fishy smell and high salt content of kimchi. Therefore, the present study aimed to identify alternative jeotgal sources and investigate the fermentation properties of jeotgal alternatives added to kimchi. The tomato hotwater extract (TH2) and dry-aged beef hot-water extract (DBH) were selected as jeotgal alternatives for kimchi preparation based on their glutamic acid contents. Characteristics of kimchi with TH2 alone (JA1) and TH2 and DBH in combination (1:1, JA2) were compared with kimchi prepared using commercially available anchovy fish sauce $(\mathrm{CON})$. The $\mathrm{pH}$ of JA1 and JA2 was slightly decreased during fermentation, whereas the salinity was significantly lower than $\mathrm{CON}(p<0.05)$. Notably, the most effective factor of the savory taste of kimchi, glutamic acid contents of JA1 and JA2 were significantly higher than that of CON $(p<0.05)$. In conclusion, JA1 showed slower fermentation with lower salinity and higher glutamic acid content than CON. Overall, this study showed that JA1 derived from $\mathrm{TH} 2$ could improve the taste and quality of kimchi by increasing glutamic acid content and decreasing the unpleasant flavor.
\end{abstract}

Keywords: Jeotgal alternative; kimchi; glutamic acid; volatile compound; savory taste

\section{Introduction}

Jeotgal (salted seafood) is a fermented food obtained by degradation of protein peptides by its enzymes and external microorganisms, imparting a unique flavor and taste to kimchi, while spoilage is prevented by adding large amounts of salt [1]. Thus, jeotgal is an important ingredient in kimchi. It contains a large amount of glutamic acid and nucleic acid-related substances such as adenosine triphosphate (ATP), adenosine diphosphate (ADP), and inosine monophosphate (IMP), responsible for the savory taste of kimchi [2-5]. However, the high salinity and unpleasant fishy smell of jeotgal makes it difficult to prepare standardized kimchi and reduces customer preferences [6], warranting the need for alternative ingredients to prepare jeotgal. Therefore, it has recently gained increasing interest. Several studies focused on addressing these problems associated with the high salinity and fishy smell while searching for alternative jeotgal that could impart on kimchi a taste similar to that of original jeotgal [7]. However, most of these studies on alternative ingredients for jeotgal have mainly demonstrated the potential of seafood and fishery products. On the contrary, the use of vegetable protein sources and/or animal protein sources as alternative jeotgal sources has not been explored yet, although studies have identified them as potential sources of umami compounds [8,9].

Apart from the previous studies, food ingredients other than seafood and fishery products containing high glutamic acid, which is closely related to savory taste, have been 
widely studied. Skurray et al. [10] studied the glutamic acid content in fresh and processed foods and reported that the glutamic acid of ripe tomato increased about 6-fold compared to that of fresh tomato. Al-Sayed et al. [11] also reported that ripe tomato is the richest source of glutamic acid among fruits and contains approximately $300 \mathrm{mg}$ of glutamic acid per $100 \mathrm{~g}$ of ripe tomatoes. Therefore, tomato is highly utilized to produce the rich flavor of broth overseas with plenty of glutamic acids, organic acid, and other ingredients [12]. As another alternative ingredient, beef is generally known to improve the savory taste according to the aging method. Dry-aging is a process where beef is placed with good air circulation at $2-4{ }^{\circ} \mathrm{C}$ and $65-85 \%$ humidity for $20-60$ days. The weight is decreased, however, the quality of beef is softened and the savory taste increases [13]. It has been shown that the free amino acid content of beef after drying and vacuum-packing increased about four times along with an increase in functional peptides such as taurine, anserine, and carnosine. In particular, the glutamic acid and IMP related to the savory taste were the highest at 40 days into the dry-aging period [14].

Here, we aimed to make kimchi using jeotgal alternatives to improve the taste and reduce the fishy smell. In this study, beef, soybean, and tomato were selected as alternative ingredients for jeotgal preparation. Protein hydrolysis processes such as enzymatic hydrolysis and hot water extraction were initially conducted to improve the savory taste. The final jeotgal alternatives for kimchi application were selected based on their glutamic acid contents. Then, physicochemical, microbial, free amino acid, and volatile compounds of kimchi prepared with jeotgal alternatives were investigated and compared to those of kimchi prepared with commercial jeotgal.

\section{Materials and Methods}

\subsection{Materials and Reagents}

The jeotgal alternative materials-beef, soybean, and tomato-were purchased from an on-line market (G-market, Seoul, Korea). Proteases (Protamex, Flavourzyme, and Alcalase) were purchased from Novo Nordisk (Bagsvaerd, Denmark). A glutamic acid assay kit was purchased from Megazyme (K-GLUT, Ireland). The kimchi ingredients, including brined kimchi cabbage, red pepper, garlic, ginger, and anchovy fish sauce, were purchased from Seobu Agricultural and Fishery Market in Gwangju (Gwangju, Korea). MRS and PCA agar plates were purchased from Kisan Bio (Seoul, Korea).

\subsection{Preparation of Jeotgal Alternative}

The jeotgal alternatives were prepared using dry-aged beef (DB), isolated soybean protein (ISP), and tomatoes in optimized powder form obtained by freeze-dying. To improve the savory taste, enzymatic hydrolysis and hot-water extraction were used as a protein processing method in each jeotgal alternative source. DB mixed with 2-folds distilled water was extracted with hot water at $90{ }^{\circ} \mathrm{C}$ for $30 \mathrm{~min}$. The solution was then filtered and centrifuged at $4000 \mathrm{rpm}$ for $30 \mathrm{~min}$. Then the supernatant was collected and freeze-dried, and the preparation was designated as DB hot water extract (DBH). Subsequently, the pellet obtained after separating the supernatant was hydrolyzed using three different protease enzymes-flavourzyme, protamex, and alcalase-each at a concentration of $1 \%$ was used for the enzymatic hydrolysis at $50^{\circ} \mathrm{C}$ for $2 \mathrm{~h}$. The hydrolyzed products were freeze-dried, and the preparations were named DBHF, DBHP, and DBHA, respectively. ISP with 10folds distilled water were hydrolyzed using the three proteases (flavourzyme, protamex, and alcalase; $1 \%$ each) at $50{ }^{\circ} \mathrm{C}$ for $4 \mathrm{~h}$, inactivated at $95{ }^{\circ} \mathrm{C}$ for $30 \mathrm{~min}$, and centrifuged at $4000 \mathrm{rpm}$ for $30 \mathrm{~min}$. The supernatant was then collected and freeze-dried, and the preparations were named ISPF, ISPP, and ISPA, respectively. The mature tomatoes with 2-folds distilled water were extracted with hot-water at $90^{\circ} \mathrm{C}$ for $1,2,3$, or $4 \mathrm{~h}$, filtered, and centrifuged at $4000 \mathrm{rpm}$ for $30 \mathrm{~min}$. The supernatant was then collected and freeze-dried, and the preparations were named $\mathrm{TH} 1, \mathrm{TH} 2, \mathrm{TH} 3$, and $\mathrm{TH} 4$, respectively. 


\subsection{Glutamic Acid Content Analysis}

To select the final jeotgal alternative, glutamic acid was measured using a Glutamic acid assay kit after protein processing. Each of the jeotgal alternative $(10 \mu \mathrm{L})$ and standard $(10 \mu \mathrm{L})$ was initially reacted with buffer $(50 \mu \mathrm{L})$, nicotinamide-adenine dinucleotide/iodonitrotetrazolium chloride (NAD + /INT, $20 \mu \mathrm{L})$, diaphorase $(5 \mu \mathrm{L})$, and distilled water $(200 \mu \mathrm{L})$ for $2 \mathrm{~min}$. Absorbance (A1) was read at $492 \mathrm{~nm}$ using a SPECTROStar Nano microplate reader (BMG LABTECH, Ortenberg, Germany). After reacting with glutamate dehydrogenase (GIDH, $5 \mu \mathrm{L}$ ), absorbance (A2) was read at $492 \mathrm{~nm}$. Glutamic acid content was calculated using the following formula:

Glutamic acid content $=[(\mathrm{A} 2-\mathrm{A} 1)$ of sample $/(\mathrm{A} 2-\mathrm{A} 1)$ of standard $\times$ standard $]$

Subsequently, the jeotgal alternative with a high glutamic acid content in each of the alternative materials was selected and their free amino acid and volatile compounds were measured compared with those of anchovy fish sauce (CON).

\subsection{Free Amino Acids Analysis}

For free amino acid analysis, the Jeotgal alternatives and kimchi samples were diluted, homogenized, and refrigerated for $15 \mathrm{~h}$. The solutions were then filtered using $0.45 \mu \mathrm{m}$ membrane filters, and the filtrate was used as the samples for further analysis. Free amino acids were analyzed using high-pressure liquid chromatography (HPLC, Ultimate 3000, Thermo Dionex, USA) equipped with a VDSpher 100 C18-E column $(4.6 \times 150 \mathrm{~mm}$, 3.5um/VDS optilab, Germany), at an oven temperature of $40^{\circ} \mathrm{C}$. The operational conditions for HPLC are shown in (Table 1 ). The amino acids were quantified by calibrating with standard amino acids (Agilent Technologies, CA, USA).

Table 1. Operational conditions for high-pressure liquid chromatography (HPLC) analysis to quantify free amino acid contents.

\begin{tabular}{cc}
\hline Parameters & Conditions \\
\hline HPLC system & Ultimate 3000 \\
Column & VDSpher $100 \mathrm{C} 18-\mathrm{E}$ \\
Mobile phase & A: $40 \mathrm{mM}$ sodium phosphate dibasic, pH 7.8 \\
Flow rate & B: water/acetonitrile $/$ methanol $(10: 45: 45 v / v \%)$ \\
Detector & $1.5 \mathrm{~mL} / \mathrm{min}$ \\
& FL Detector $1260 \mathrm{FLD}$ \\
& $:$ Emission $450 \mathrm{~nm}$, Excitation $340 \mathrm{~nm}(\mathrm{OPA})$ \\
& UV Detector \\
& $: 338 \mathrm{~nm}$ \\
& Oven Temperature $40{ }^{\circ} \mathrm{C}$ \\
\hline
\end{tabular}

\subsection{Volatile Compounds Analysis}

Volatile compounds extracted using solid-phase microextraction (SPME) fibers (DVB/CAR/PDMS, 50/30 $\mu \mathrm{M}$, Supelco-57329-U) were analyzed using a gas chromatographymass spectrometer (GC/MS 7890A, Agilent Technologies, SC, USA) with an autosampler (Multi-Purpose Sample with DHS option, MPS, Gerstel, Germany). All samples were placed in a $10 \mathrm{~mL}$, sealed with an aluminum cap, and then absorbed onto polydimethylsiloxane (PDMS) fiber at $100 \mathrm{rpm}$ for $30 \mathrm{~min}$ at $50{ }^{\circ} \mathrm{C}$. The SPME fiber, which extracted the volatile compounds, was automatically injected into a gas chromatography-mass spectrometer (GC/MS) injection port, and the volatile compounds were thermally desorbed at $250{ }^{\circ} \mathrm{C}$ for $3 \mathrm{~min}$ and analyzed using GC/MS. Electron impact ionization $(70 \mathrm{eV})$ was performed at a full scan range of $50-550 \mathrm{~m} / z$. The volatile compound was identified based on a mass spectral library (WILEY 10N). The operational conditions for GS/MS analysis are shown in (Table 2). 
Table 2. Operational conditions for gas chromatography-mass spectrometer (GS/MS) analysis to quantify volatile compounds.

\begin{tabular}{cc}
\hline Parameters & Conditions \\
\hline GC System with MS & Agilent 7890 with 5977BA \\
Separation column & DB-WAX $(60 \mathrm{~m} \times 0.25 \mathrm{~mm} \times 0.25 \mu \mathrm{M})$ \\
Injection temperature & $250{ }^{\circ} \mathrm{C}$ \\
Carrier gas flow & $1 \mathrm{~mL} / \mathrm{min}(\mathrm{He})$ \\
Oven temperature & $40^{\circ} \mathrm{C}(3 \mathrm{~min}) \rightarrow 150^{\circ} \mathrm{C}\left(2{ }^{\circ} \mathrm{C} / \mathrm{min}\right)(10 \mathrm{~min}) \rightarrow 200^{\circ} \mathrm{C}\left(4^{\circ} \mathrm{C} / \mathrm{min}\right)(10)$ \\
\hline
\end{tabular}

\subsection{Preparation of Kimchi by Adding Jeotgal Alternative}

Based on the high glutamic acid content, DBH and TH2 were selected for kimchi preparation (see Section 3.1). According to the kimchi recipe (Table 3), kimchi was prepared by replacing anchovy fish sauce with TH2 alone (JA1) or TH2 and DBH (1:1; JA2), and kimchi with anchovy fish sauce was used as a control (CON). Kimchi was stored and fermented at $10^{\circ} \mathrm{C}$ for 2 weeks, and its physicochemical properties, microbial properties, free amino acid contents, and volatile compound composition were examined on weeks 0 , 1 , and 2 , where week " 0 " represents the data before fermentation.

Table 3. Ingredients used to prepare kimchi with commercial and jeotgal alternatives.

\begin{tabular}{cccc}
\hline Ingredient & $\begin{array}{c}\text { CON } \\
(\mathbf{g})\end{array}$ & $\begin{array}{c}\text { JA1 } \\
(\mathbf{g})\end{array}$ & $\begin{array}{c}\text { JA2 } \\
(\mathbf{g})\end{array}$ \\
\hline Brined Kimchi cabbage & 700 & 700 & 700 \\
Red pepper & 66 & 66 & 66 \\
Garlic & 36 & 36 & 36 \\
Ginger & 10.2 & 10.2 & 10.2 \\
Rice paste & 57.3 & 57.3 & 57.3 \\
Water & 98.1 & 98.1 & 98.1 \\
Sugar & 1.5 & 1.5 & 1.5 \\
Salt & 2.28 & 2.28 & 2.28 \\
Jeotgal & 28.62 & - & - \\
DBH & - & - & 14.31 \\
TH2 & - & 28.62 & 14.31 \\
\hline Total & 1000 & 1000 & 1000 \\
\hline
\end{tabular}

\subsection{Physicochemical Analysis}

The $\mathrm{pH}$ was measured with a $\mathrm{pH}$ meter (pH Electrode blue line 12, SCHORR Instrument, Germany) after kimchi sample blending, and total acidity was titrated with $0.1 \mathrm{~N}$ $\mathrm{NaOH}$ until $\mathrm{pH}$ reached 8.3. Salinity was measured by Mohr's titration [15]. In brief, the kimchi juice was diluted with distilled water $(1 / 100)$ and then filtered. After adding $2 \%$ potassium chromate as the indicator $(1 \mathrm{~mL})$, the mixture was titrated against $0.02 \mathrm{~N} \mathrm{AgNO}_{3}$ until reaching the endpoint based on a detectable change to a red-brown color.

\subsection{Microbial Analysis}

Microbial analysis for total viable bacteria and lactic acid bacteria was conducted using a pre-made plate count agar (PCA) plate and deMan-Rogosa Sharpe (MRS) agar plate. To measure the total viable bacteria, kimchi samples were diluted to $10^{1}$ to $10^{7}$. Diluted kimchi samples $(100 \mu \mathrm{L})$ were evenly spread on a PCA plate (Kisan Bio, Seoul, Korea) and incubated at $37^{\circ} \mathrm{C}$ for 2 days. Total viable bacteria was measured by counting in the cultured PCA plate. To measure the lactic acid bacteria, diluted kimchi samples were inoculated on an MRS agar plate (Kisan Bio, Seoul, Korea), and then incubated at $37^{\circ} \mathrm{C}$ for 2 days under an anaerobic condition. After incubation, the lactic acid bacteria in the MRS agar plate was counted. 


\subsection{Statistical Analysis}

Each experiment was conducted in triplicate, and the results were expressed as the mean and standard deviation (SD). All data were analyzed one-way analysis of variance analysis (ANOVA), and significant differences were analyzed by Duncan's multiple range test $(p<0.05)$ using the GraphPad Prism 7 (GraphPad Software Inc., San Diego, CA, USA).

\section{Results and Discussion}

\subsection{Glutamic Acid Content of Jeotgal Alternative}

The glutamic acid contents of the jeotgal alternatives are shown in (Figure 1). Among the enzymatically digested ISP, ISPA showed the highest glutamic acid as $0.02 \mathrm{mg} / \mathrm{mL}$, consistent with Valerio's findings [16], which showed a similar low glutamic acid content in the formulation of yeast-leavened bread. Hot water extraction in DB significantly increased glutamic acid content compared with enzymatic digestion $(p<0.05)$, however, among the enzymatically hydrolyzed preparations, DBHA showed the highest glutamic acid content. In the TH sample extracted with hot water (TH1-TH4), glutamic acid content was significantly increased in TH2 compared to the other three formulations $(p<0.05)$. Overall, among the jeotgal alternatives, the glutamic acid content of ISPA was relatively lower than that of other alternatives. Taken together, the findings revealed the highest glutamic acid content in ISPA, the preparation obtained by enzymatic hydrolysis of ISP with $1 \%$ alcalase at $50^{\circ} \mathrm{C}$ for $4 \mathrm{~h}$. Of the hot water extract and enzymatically hydrolyzed preparations of DB, DBH had a higher glutamic acid content than DBHA, DBHP, and DBHF, wherein the glutamic acid content of DBHA was maximum among the three enzymatically hydrolyzed preparations of DB. Moreover, of the four ripe tomato hot-water extracts, TH2 showed the highest glutamic acid content. Based on these results, ISPA, DBH, and TH2 were initially selected as jeotgal alternatives for the kimchi preparation.

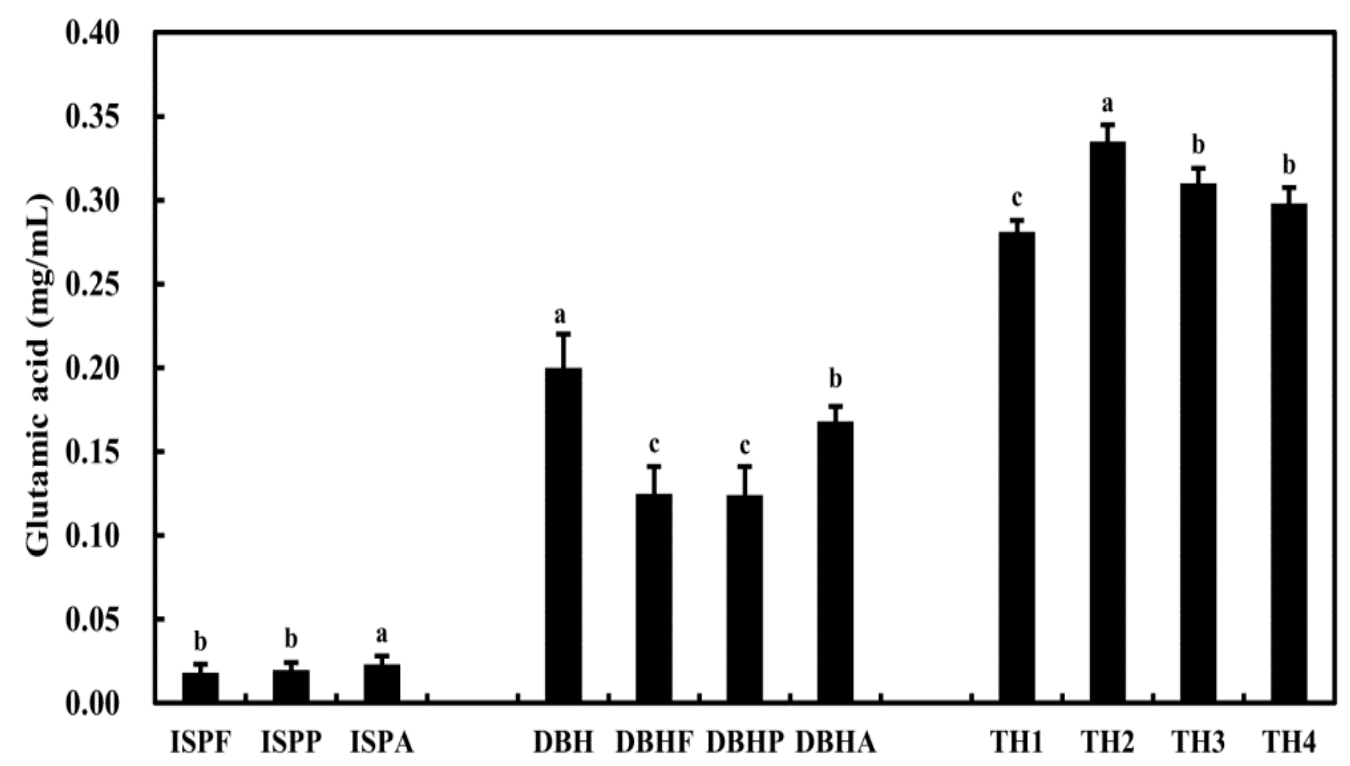

Figure 1. Glutamic acid content of jeotgal alternative materials after the enzymatic digestion process. Isolated soybean protein (ISP), dry-aged beef (DB), and tomato (T). Data are expressed as means \pm SD. Different lowercase letters indicate a significant difference in the same jeotgal alternative $(p<0.05)$.

ISPF, ISPP, and ISPA, Enzymatic hydrolysis of ISP with flavourzyme, protamex, and alcalase at $50{ }^{\circ} \mathrm{C}$ for $4 \mathrm{~h}$. DBH, DB with hot water extraction at $90^{\circ} \mathrm{C}$ for $2 \mathrm{~h}$; DBHF, DBHP, DBHA, enzymatic hydrolysis of DBH with flavourzyme, protamex, and alcalase at $50{ }^{\circ} \mathrm{C}$ for $2 \mathrm{~h}$. TH1, $\mathrm{TH} 2, \mathrm{TH} 3$, and $\mathrm{TH} 4$, tomato with hot water extraction at $90{ }^{\circ} \mathrm{C}$ for $1,2,3$, and $4 \mathrm{~h}$. 


\subsection{Free Amino Acid Composition of Selected Jeotgal Alternative}

The amino acids, including glutamic acid, alanine, and glycine, are the main components that contribute to the unique savory taste of jeotgal, whereas the amino acids, including leucine, isoleucine, and arginine, responsible for bitterness, are known to affect the quality of jeotgal negatively [1]. As shown in (Table 4), TH2 showed the highest glutamic acid contents at $33,328.32 \mathrm{mg} / \mathrm{kg}$, followed by commercial jeotgal at $21,032.41 \mathrm{mg} / \mathrm{kg}$. The glycine content was the highest in DBH $(4025.58 \mathrm{mg} / \mathrm{kg})$ among the jeotgal alternatives; however, it was similar to that of commercial jeotgal $(4841.74 \mathrm{mg} / \mathrm{kg})$. The alanine content of DBH $(14,997.51 \mathrm{mg} / \mathrm{kg})$ was higher than that of commercial jeotgal $(9501.16 \mathrm{mg} / \mathrm{kg})$. However, the contents of these three amino acids were lowest in ISPA. Furthermore, the contents of leucine, isoleucine, and arginine were the highest in commercial jeotgal, followed by DBH, TH2, and ISPA, in that order. The content of most of the amino acids was low in ISPA in addition to the maximum number of not detectable (ND) amino acids that included taurine and gamma-aminobutyric acid (GABA). As shown in (Table 4), taurine and GABA were detected only in CON and TH2, respectively. Taken together, TH2 or DBH alone or in combination were speculated to maintain the savory taste of commercial jeotgal and reduce the bitterness when used in kimchi. Therefore, TH2 and DBH were used as high potential jeotgal alternatives for kimchi preparation.

Table 4. Free amino acid composition of jeotgal alternatives.

\begin{tabular}{|c|c|c|c|c|}
\hline $\begin{array}{l}\text { Free Amino } \\
\text { Acids }\end{array}$ & $\begin{array}{c}\mathrm{CON} \\
(\mathrm{mg} / \mathrm{kg})\end{array}$ & $\begin{array}{c}\mathrm{DBH} \\
(\mathrm{mg} / \mathrm{kg})\end{array}$ & $\begin{array}{c}\text { ISPA } \\
(\mathrm{mg} / \mathrm{kg})\end{array}$ & $\begin{array}{c}\mathrm{TH} 2 \\
(\mathrm{mg} / \mathrm{kg})\end{array}$ \\
\hline Aspartic acid & $12,591.76 \pm 65.40^{\mathrm{a}}$ & $488.85 \pm 31.64^{c}$ & $57.78 \pm 3.00^{d}$ & $8425.89 \pm 77.47^{b}$ \\
\hline Glutamic acid & $21,032.41 \pm 407.62^{b}$ & $7815.70 \pm 332.44^{\mathrm{c}}$ & $192.49 \pm 9.41^{\mathrm{d}}$ & $33,328.32 \pm 212.79^{a}$ \\
\hline Asparagine & $85.72 \pm 1.90^{c}$ & $2152.63 \pm 110.63^{b}$ & $110.74 \pm 4.28^{c}$ & $4515.82 \pm 21.08^{a}$ \\
\hline Serine & $6548.43 \pm 78.05^{a}$ & $5163.78 \pm 306.21^{a}$ & $132.22 \pm 6.92^{c}$ & $1169.69 \pm 6.54^{b}$ \\
\hline Glutamine & $117.89 \pm 4.17^{\mathrm{c}}$ & $18,764.66 \pm 945.22^{a}$ & $37.89 \pm 0.46^{\mathrm{d}}$ & $6278.53 \pm 8.15^{b}$ \\
\hline Histidine & $6141.59 \pm 250.82^{a}$ & $2128.26 \pm 105.86^{b}$ & $122.26 \pm 1.35^{\mathrm{d}}$ & $773.99 \pm 0.41^{c}$ \\
\hline Glycine & $4841.74 \pm 8.73^{a}$ & $4025.58 \pm 464.57^{\mathrm{a}}$ & $26.02 \pm 1.87^{c}$ & $160.82 \pm 3.76^{b}$ \\
\hline Threonine & $7394.65 \pm 48.64^{a}$ & $3983.79 \pm 173.73^{b}$ & $31.62 \pm 0.62^{d}$ & $1997.02 \pm 3.13^{c}$ \\
\hline Arginine & $6246.24 \pm 22.23^{a}$ & $4173.57 \pm 655.57^{b}$ & $212.44 \pm 18.74 \mathrm{~d}$ & $1468.70 \pm 43.62^{c}$ \\
\hline Alanine & $9501.16 \pm 35.15^{b}$ & $14,997.51 \pm 655.57^{\mathrm{a}}$ & $145.19 \pm 5.38^{d}$ & $666.53 \pm 35.05^{c}$ \\
\hline Taurine & $2189.53 \pm 38.50$ & ND & ND & ND \\
\hline GABA & ND & ND & ND & $7467.79 \pm 139.30$ \\
\hline Tyrosine & $668.90 \pm 64.66^{b}$ & $2976.79 \pm 86.99^{a}$ & $126.07 \pm 28.41^{\mathrm{d}}$ & $474.99 \pm 37.33^{c}$ \\
\hline Valine & $7689.68 \pm 26.09$ & $4440.78 \pm 121.56$ & ND & $324.92 \pm 9.16$ \\
\hline Methionine & $2744.33 \pm 2.94$ & $2543.58 \pm 100.97$ & ND & $193.65 \pm 9.11$ \\
\hline Tryptophane & $1721.02 \pm 13.16$ & $845.61 \pm 53.55$ & ND & $469.91 \pm 10.98$ \\
\hline Phenylalanine & $4437.97 \pm 40.53$ & $3226.94 \pm 158.98$ & ND & $1650.90 \pm 22.61$ \\
\hline Isoleucine & $4919.20 \pm 52.41$ & $3221.46 \pm 124.82$ & ND & $563.90 \pm 4.58$ \\
\hline Leucine & $6295.06 \pm 47.16^{\mathrm{a}}$ & $5884.54 \pm 249.84^{\mathrm{a}}$ & $128.94 \pm 1.70^{\mathrm{c}}$ & $782.21 \pm 10.40^{b}$ \\
\hline Lysine & $11,471.60 \pm 40.38^{a}$ & $6181.05 \pm 1019.20^{b}$ & $221.65 \pm 7.68^{d}$ & $782.21 \pm 10.40^{c}$ \\
\hline Proline & $2565.24 \pm 122.12$ & $2629.67 \pm 380.10$ & $\mathrm{ND}$ & $192.56 \pm 12.43$ \\
\hline
\end{tabular}

ND: not detected. Data are expressed as mean \pm SD. Different letters are significantly different among groups $(p<0.05)$.

\subsection{Volatile Compounds Composition of Jeotgal Alternatives}

Volatile compounds of jeotgal alternatives were identified and quantified using the internal standard materials. As shown in Table 5, volatile compounds in CON were detected in the order of 3-methylbutanoic acid, 2,4-bis(1,1-dimethylethyl) phenol, and butanoic acid. Among these, 3-methylbutanoic acid is closely related to the unpleasant flavor of jeotgal and imparts a rancid, cheesy, sweaty flavor [17]. In a dry porcini mushroom (Boletus edulis) study, 3-methylbutanoic acid has also been described to impart a lactic or sweaty aroma [18], whereas butanoic acid provides a cheesy note to roasted shrimp [19]. Furthermore, the volatile compound composition of DBH identified 2,4-bis(1,1-dimethylethyl) phenol as the major compound, followed by trimethylpyrazine and butanoic acid. Of 
these, trimethylpyrazine has been identified as a flavor compound in roasted coffee beans, cooked rice, and soy paste [20,21]. In ISPA, only 2,4-bis(1,1-dimethylethyl) phenol and acetic acid were detected; however, the other volatile compounds were hardly detected. The major volatile compound of TH2 was 2,4-bis(1,1-dimethylethyl) phenol, followed by acetic acid at a low content. These results demonstrated a more or less similar profile of volatile compounds in $\mathrm{CON}$ and $\mathrm{DBH}$, which have animal protein bases, which differed significantly from that of ISPA and TH2, having vegetable protein bases. It is noteworthy that 3-methylbutanoic acid was dramatically decreased in all three jeotgal alternatives, indicating their potential to reduce the unpleasant fishy smell of kimchi. However, 2,4Bis(1,1-dimethylethyl) phenol and butanoic acid are significantly higher in DBH than those in TH2. Taken together, it can be inferred that TH2 with a desirable profile of volatile compounds and higher glutamic acid content than commercial jeotgal could be the best jeotgal alternative.

Table 5. Volatile compounds composition of commercial jeotgal (CON) and jeotgal alternatives (DBH, ISPA, and TH2).

\begin{tabular}{|c|c|c|c|c|}
\hline Volatile Compounds ${ }^{1}$ & $\begin{array}{c}\text { CON } \\
\text { (Peak Area) }\end{array}$ & $\begin{array}{c}\text { DBH } \\
\text { (Peak Area) }\end{array}$ & $\begin{array}{c}\text { ISPA } \\
\text { (Peak Area) }\end{array}$ & $\begin{array}{c}\text { TH2 } \\
\text { (Peak Area) }\end{array}$ \\
\hline 2,4-Bis(1,1-dimethylethyl) phenol & $0.53 \pm 0.19^{\mathrm{NS}}$ & $2.68 \pm 0.75$ & $0.07 \pm 0.00$ & $0.46 \pm 0.15$ \\
\hline 2,5-Dimethylpyrazine & $0.12 \pm 0.04^{b}$ & $0.30 \pm 0.10^{a}$ & $0.00 \pm 0.00^{c}$ & $0.00 \pm 0.00^{c}$ \\
\hline 2-Furanmethanol & $0.14 \pm 0.05$ & ND & ND & $0.01 \pm 0.00$ \\
\hline 2-Methylpentanoic acid & $0.11 \pm 0.04$ & ND & $0.00 \pm 0.00$ & ND \\
\hline 2-Methylpropanoic acid & $0.14 \pm 0.05$ & $0.03 \pm 0.01$ & ND & ND \\
\hline 3-Methylbutanoic acid & $1.79 \pm 0.57^{\mathrm{a}}$ & $0.06 \pm 0.02^{b}$ & $0.00 \pm 0.00^{b}$ & $0.01 \pm 0.00^{b}$ \\
\hline 4-Methylpentanoic acid & $0.10 \pm 0.03$ & $0.01 \pm 0.00$ & ND & ND \\
\hline Acetic acid & $0.11 \pm 0.04^{\mathrm{b}}$ & $0.42 \pm 0.14^{\mathrm{a}}$ & $0.01 \pm 0.00^{\mathrm{c}}$ & $0.07 \pm 0.01^{b}$ \\
\hline Benzaldehyde & $0.17 \pm 0.05^{\mathrm{a}}$ & $0.00 \pm 0.00^{b}$ & $0.00 \pm 0.00^{b}$ & $0.01 \pm 0.00^{b}$ \\
\hline Butanoic acid & $0.37 \pm 0.12^{b}$ & $0.59 \pm 0.21^{\mathrm{a}}$ & $0.00 \pm 0.00^{c}$ & $0.00 \pm 0.00^{c}$ \\
\hline Phenol & $0.10 \pm 0.03^{\mathrm{a}}$ & $0.00 \pm 0.00^{b}$ & $0.00 \pm 0.00^{b}$ & $0.01 \pm 0.00^{b}$ \\
\hline Trimethylpyrazine & $0.15 \pm 0.05$ & $1.31 \pm 0.47$ & ND & $0.00 \pm 0.00$ \\
\hline
\end{tabular}

ND: not detected. ${ }^{1}$ All volatile compounds were identified by comparison with mass spectra and retention index database. Data are expressed as mean \pm SD. Different letters are significantly different among groups $(p<0.05)$, NS: not significant.

\section{4. pH, Total Acidity, and Salinity of Kimchi Prepared with Jeotgal Alternatives}

Table 6 shows the $\mathrm{pH}$, total acidity, and salinity of kimchi prepared with the jeotgal alternatives-JA1 and JA2. On week 0 , the $\mathrm{pH}$ of JA2 was significantly higher than that of CON and JA1. However, the $\mathrm{pH}$ of JA1 was the lowest (4.54), and this could be due to the influence of the ingredients of JA2, such as tomatoes, which are acidic foods [22]. On week 1 , the $\mathrm{pH}$ of $\mathrm{CON}$ was rapidly decreased to 4.35 , while that of JA1 was decreased to 4.41. The $\mathrm{pH}$ of JA2 was also decreased, but the decrease was less than that of the CON. Similarly, on week 2, the $\mathrm{pH}$ of the CON decreased rapidly compared to JA1 and JA2. These results indicated the effect of jeotgal alternatives on fermentation delay by slowing the decrease in $\mathrm{pH}$. In general, the $\mathrm{pH}$ was changed due to the organic acid produced by the decomposition of carbohydrates in kimchi ingredients and affected the taste of kimchi. These results are consistent with a previous study that reported similar trends of decrease with the progression of the kimchi fermentation process [23].

Total acidity was gradually increased in all groups, and JA2 showed the highest total acidity of $1.36 \%$ on week 2 . Surprisingly, the salinity showed a significant difference among groups. Compared to CON (1.87\%), the salinities of JA1 and JA2 were significantly lower $(p<0.05,1.13 \%$, and $1.03 \%$, respectively). These results indicate that jeotgal alternatives can improve the high salinity problem of jeotgal by reducing the salinity of kimchi. Taken together, the findings suggest that the jeotgal alternatives could lower the saltiness of kimchi and delay its fermentation. 
Table 6. Changes in $\mathrm{pH}$, total acidity, and salinity of kimchi prepared with jeotgal alternatives.

\begin{tabular}{ccccc}
\hline Week & Samples & $\mathbf{p H}$ & $\begin{array}{c}\text { Total Acidity } \\
\mathbf{( \% )}\end{array}$ & $\begin{array}{c}\text { Salinity } \\
\mathbf{( \% )}\end{array}$ \\
\hline \multirow{2}{*}{0} & CON & $4.90 \pm 0.00^{\mathrm{a}}$ & $0.50 \pm 0.01^{\mathrm{c}}$ & $1.87 \pm 0.04^{\mathrm{a}}$ \\
& JA1 & $4.54 \pm 0.02^{\mathrm{c}}$ & $0.79 \pm 0.00^{\mathrm{a}}$ & $1.13 \pm 0.03^{\mathrm{b}}$ \\
& JA2 & $4.94 \pm 0.01^{\mathrm{b}}$ & $0.69 \pm 0.00^{\mathrm{b}}$ & $1.03 \pm 0.02^{\mathrm{b}}$ \\
\hline \multirow{2}{*}{1} & CON & $4.35 \pm 0.01^{\mathrm{c}}$ & $0.73 \pm 0.01^{\mathrm{c}}$ & $1.85 \pm 0.00^{\mathrm{a}}$ \\
& JA1 & $4.41 \pm 0.01^{\mathrm{b}}$ & $0.85 \pm 0.01^{\mathrm{b}}$ & $1.13 \pm 0.01^{\mathrm{b}}$ \\
& JA2 & $4.55 \pm 0.02^{\mathrm{a}}$ & $0.97 \pm 0.01^{\mathrm{a}}$ & $1.03 \pm 0.02^{\mathrm{b}}$ \\
\hline \multirow{2}{*}{2} & CON & $4.03 \pm 0.01^{\mathrm{c}}$ & $1.12 \pm 0.02^{\mathrm{b}}$ & $1.85 \pm 0.01^{\mathrm{a}}$ \\
& JA1 & $4.23 \pm 0.01^{\mathrm{b}}$ & $1.15 \pm 0.01^{\mathrm{b}}$ & $1.12 \pm 0.00^{\mathrm{b}}$ \\
& JA2 & $4.31 \pm 0.02^{\mathrm{a}}$ & $1.36 \pm 0.02^{\mathrm{a}}$ & $1.02 \pm 0.02^{\mathrm{b}}$ \\
\hline
\end{tabular}

Data are expressed as mean \pm SD. Different letters are significantly different among groups $(p<0.05)$.

\subsection{Microbial Profiles of Kimchi Prepared with Jeotgal Alternatives}

The microbial changes are shown in (Table 7). The total viable cell showed a similar level in different groups $(6.93 \sim 7.02 \mathrm{CFU} / \mathrm{mL})$ on week 0 , which was increased on week 1 in all groups; however, CON showed the highest level $(8.19 \mathrm{CFU} / \mathrm{mL})$. On week 2, the total viable cell increased from 8.49 to $8.83 \mathrm{CFU} / \mathrm{mL}$ and was the highest in JA1. Similarly, lactic acid bacteria showed similar results. $\mathrm{CON}$ and JA1 showed the highest lactic acid bacteria on weeks 1 and 2, respectively. Inconsistent with these results, Choi et al. reported that total viable cell counts reached the maximum of approximately 15 to 18 days and then rapidly decreased [24]. In the present study, the microbial changes were similar between CON and jeotgal alternatives at $10^{\circ} \mathrm{C}$, and the lactic acid bacteria of jeotgal alternative was higher than $\mathrm{CON}$ on week 2 . These results indicated that jeotgal alternatives could maintain kimchi fermentation qualities by preserving the microbial properties.

Table 7. Microbial changes of kimchi prepared with jeotgal alternatives.

\begin{tabular}{|c|c|c|c|}
\hline Week & Samples & Total Viable Bacteria (CFU/mL) & Lactic Acid Bacteria (CFU/mL) \\
\hline \multirow{3}{*}{0} & $\mathrm{CON}$ & $6.93 \pm 0.03^{b}$ & $6.87 \pm 0.02^{\mathrm{NS}}$ \\
\hline & JA1 & $7.02 \pm 0.01^{\mathrm{a}}$ & $6.88 \pm 0.05$ \\
\hline & JA2 & $6.98 \pm 0.03^{b}$ & $6.84 \pm 0.02$ \\
\hline \multirow{3}{*}{1} & $\mathrm{CON}$ & $8.19 \pm 0.06^{\mathrm{a}}$ & $8.00 \pm 0.05^{\mathrm{NS}}$ \\
\hline & JA1 & $7.93 \pm 0.05^{b}$ & $7.80 \pm 0.07$ \\
\hline & JA2 & $7.99 \pm 0.04^{b}$ & $7.91 \pm 0.01$ \\
\hline \multirow{3}{*}{2} & $\mathrm{CON}$ & $8.49 \pm 0.01^{b}$ & $8.50 \pm 0.05^{b}$ \\
\hline & JA1 & $8.83 \pm 0.05^{\mathrm{a}}$ & $8.74 \pm 0.05^{\mathrm{a}}$ \\
\hline & JA2 & $8.51 \pm 0.12^{b}$ & $8.42 \pm 0.04^{b}$ \\
\hline
\end{tabular}

Data are expressed as mean \pm SD. Different letters are significantly different among groups $(p<0.05)$, NS: not significant.

\subsection{Free Amino Acid Composition of Kimchi Added Jeotgal Alternatives}

Changes in free amino acids were summarized in (Table 8). On week 0 , the glutamic acid content of JA1 was the highest at $1246.23 \mathrm{mg} / \mathrm{kg}$. Even though kimchi was prepared with a similar amino acid level in all groups, the glutamic acid content of JA1 and JA2 was higher than that of $\mathrm{CON}$ on week 0 . In particular, the glutamic acid content of JA1 was the highest during the kimchi fermentation period, which was approximately 3-folds higher than that of CON. Regarding glycine content, CON showed the highest level on week 0 , wherein JA2 showed the highest level on weeks 1 and 2. Similarly, JA2 showed the highest alanine content on all weeks. Consistent with the result of week 0 , free amino acid contents of JA1 and JA2 were higher at 1 and 2 weeks than in CON. Notably, leucine and isoleucine contents, contributing to bitterness [4], were lower in JA1 and JA2 than CON on week 1; however, the arginine content was slightly higher than that in CON. Similar 
results were also observed on weeks 0 and 2. According to a previous study, these changes in free amino acid during kimchi fermentation are mainly caused by a proteolytic reaction of the protein of jeotgal and greatly affect the taste of kimchi $[25,26]$. Uniquely, JA2 showed the highest taurine content in all weeks. Moreover, the GABA content in JA1 and JA2 was higher than that in CON. Based on these results, it can be inferred the jeotgal alternatives could increase the savory flavor of kimchi, leading to improved kimchi quality.

Table 8. Free amino acid composition of kimchi prepared with jeotgal alternatives.

\begin{tabular}{|c|c|c|c|c|}
\hline Free Amino Acids & Week & $\begin{array}{c}\mathrm{CON} \\
(\mathrm{mg} / \mathrm{kg})\end{array}$ & $\begin{array}{c}\text { JA1 } \\
\text { (mg/kg) }\end{array}$ & $\begin{array}{c}\mathrm{JA} 2 \\
(\mathrm{mg} / \mathrm{kg})\end{array}$ \\
\hline \multirow{3}{*}{ Glutamic acid } & 0 & $413.25 \pm 2.19^{c}$ & $1246.23 \pm 6.95^{\mathrm{a}}$ & $686.59 \pm 1.67^{b}$ \\
\hline & 1 & $428.60 \pm 3.65^{c}$ & $1057.81 \pm 1.38^{a}$ & $796.84 \pm 6.81^{b}$ \\
\hline & 2 & $466.21 \pm 2.88^{c}$ & $1231.37 \pm 10.95^{a}$ & $910.89 \pm 18.50^{b}$ \\
\hline \multirow{3}{*}{ Glycine } & 0 & $106.31 \pm 0.83^{a}$ & $55.63 \pm 0.45^{b}$ & $95.48 \pm 0.03^{a}$ \\
\hline & 1 & $114.99 \pm 1.65^{b}$ & $59.46 \pm 0.21^{c}$ & $124.98 \pm 1.82^{\mathrm{a}}$ \\
\hline & 2 & $125.06 \pm 0.30^{b}$ & $63.12 \pm 0.25^{c}$ & $145.24 \pm 2.88^{a}$ \\
\hline \multirow{3}{*}{ Arginine } & 0 & $429.60 \pm 3.92^{b}$ & $467.05 \pm 1.70^{a}$ & $446.23 \pm 0.86^{b}$ \\
\hline & 1 & $443.33 \pm 6.29^{b}$ & $462.16 \pm 2.55^{b}$ & $514.60 \pm 4.76^{\mathrm{a}}$ \\
\hline & 2 & $460.33 \pm 4.11^{b}$ & $487.34 \pm 9.22^{b}$ & $569.39 \pm 12.09^{a}$ \\
\hline \multirow{3}{*}{ Alanine } & 0 & $513.44 \pm 3.09^{b}$ & $412.26 \pm 1.32^{c}$ & $533.65 \pm 2.09^{a}$ \\
\hline & 1 & $526.47 \pm 7.12^{b}$ & $408.20 \pm 1.89^{c}$ & $718.40 \pm 7.18^{a}$ \\
\hline & 2 & $572.12 \pm 4.73^{b}$ & $428.67 \pm 4.48^{c}$ & $783.50 \pm 16.69^{a}$ \\
\hline \multirow{3}{*}{ Taurine } & 0 & $46.13 \pm 1.11^{b}$ & $26.50 \pm 0.12^{b}$ & $293.33 \pm 1.84^{a}$ \\
\hline & 1 & $44.96 \pm 1.03^{b}$ & $23.96 \pm 0.54^{b}$ & $313.50 \pm 2.68^{a}$ \\
\hline & 2 & $44.70 \pm 0.66^{b}$ & $25.11 \pm 0.18^{b}$ & $341.98 \pm 5.40^{\mathrm{a}}$ \\
\hline \multirow{3}{*}{ GABA } & 0 & $243.81 \pm 4.16^{\mathrm{c}}$ & $477.81 \pm 1.06^{\mathrm{a}}$ & $342.11 \pm 1.88^{b}$ \\
\hline & 1 & $230.97 \pm 3.67^{c}$ & $433.86 \pm 1.94^{\mathrm{a}}$ & $363.28 \pm 4.60^{b}$ \\
\hline & 2 & $224.44 \pm 2.64^{\mathrm{c}}$ & $463.39 \pm 2.54^{a}$ & $352.96 \pm 6.16^{b}$ \\
\hline \multirow{3}{*}{ Leucine } & 0 & $133.04 \pm 1.17^{a}$ & $75.18 \pm 1.14^{c}$ & $98.13 \pm 0.13^{b}$ \\
\hline & 1 & $139.06 \pm 1.77^{a}$ & $81.77 \pm 0.28^{c}$ & $124.31 \pm 1.66^{b}$ \\
\hline & 2 & $141.77 \pm 1.52^{\mathrm{a}}$ & $79.97 \pm 0.92^{\mathrm{c}}$ & $129.32 \pm 3.03^{b}$ \\
\hline \multirow{3}{*}{ Isoleucine } & 0 & $169.45 \pm 0.87^{\mathrm{a}}$ & $83.12 \pm 1.01^{\mathrm{c}}$ & $142.35 \pm 0.83^{b}$ \\
\hline & 1 & $194.37 \pm 1.75^{\mathrm{a}}$ & $102.10 \pm 0.17^{b}$ & $192.46 \pm 3.33^{a}$ \\
\hline & 2 & $218.71 \pm 1.61^{\mathrm{a}}$ & $113.11 \pm 1.00^{b}$ & $228.27 \pm 4.46^{\mathrm{a}}$ \\
\hline
\end{tabular}

Data are expressed as mean \pm SD. Different letters are significantly different among groups $(p<0.05)$.

\subsection{Volatile Compounds Composition of Prepared with Jeotgal Alternatives}

The composition of the volatile compounds is shown in (Table 9). A total of 56 volatile compounds were detected in kimchi added jeotgal alternatives for 2 weeks. On week 0, 4-isothiocyanato-1-butene showed the highest content in all groups, followed by 2-isothiocyanato-ethylbenzene. Both 4-isothiocyanato-1-butene and 2-isothiocyanatoethylbenzene dramatically decreased during kimchi fermentation in all groups. 4-isothiocyanato-1-butene is mainly produced by sinigrin hydrolysis of glucosinolates during the crushing and cooking process of cabbage and exhibits the characteristic and irritating flavor of the cruciferous plant [27]. Moreover, 3,7-dimethyl-2,6-octadienal, methyl 2-propenyl trisulfide, and zingiberene were decreased, while 2,3-butanediol, diallyl disulfide, and acetic acid were increased during kimchi fermentation. Interestingly, methyl 2-propenyl trisulfide showed the highest content on week 1 and then decreased on week 2. Consistent with our results, several previous studies have reported high contents of sulfur compounds in kimchi [28-31]. For example, Kang et al. reported high contents of sulfur compounds such as allyl methyl sulfide, dimethyl disulfide, methyl propyl disulfide, dimethyl trisulfide, and di-2-propenyl trisulfide in kimchi [28]. 
Table 9. Volatile compounds composition in kimchi prepared with jeotgal alternatives.

\begin{tabular}{|c|c|c|c|c|}
\hline Volatile Compounds ${ }^{1}$ & Week & $\begin{array}{c}\text { CON } \\
\text { (Peak Area) }\end{array}$ & $\begin{array}{c}\text { JA1 } \\
\text { (Peak Area) }\end{array}$ & $\begin{array}{c}\text { JA2 } \\
\text { (Peak Area) }\end{array}$ \\
\hline \multirow{3}{*}{ (2-Isothiocyanatoethyl) benzene } & 0 & $2.12 \pm 0.20^{a}$ & $1.84 \pm 0.08^{b}$ & $2.18 \pm 0.11^{\mathrm{a}}$ \\
\hline & 1 & $0.73 \pm 0.05^{b}$ & $0.91 \pm 0.04^{\mathrm{a}}$ & $0.64 \pm 0.05^{b}$ \\
\hline & 2 & $0.26 \pm 0.06^{b}$ & $0.26 \pm 0.00^{b}$ & $0.36 \pm 0.02^{\mathrm{a}}$ \\
\hline \multirow{3}{*}{ 2,3-Butanediol } & 0 & $0.06 \pm 0.01^{\mathrm{NS}}$ & $0.07 \pm 0.03$ & $0.07 \pm 0.01$ \\
\hline & 1 & $0.16 \pm 0.03^{b}$ & $0.17 \pm 0.00^{b}$ & $0.32 \pm 0.07^{\mathrm{a}}$ \\
\hline & 2 & $1.09 \pm 0.13^{c}$ & $1.60 \pm 0.10^{b}$ & $2.39 \pm 0.69^{a}$ \\
\hline \multirow{3}{*}{ 3,7-Dimethyl-2,6-octadien-1-ol } & 0 & $1.67 \pm 0.21^{\mathrm{a}}$ & $1.13 \pm 0.07^{b}$ & $1.01 \pm 0.09^{b}$ \\
\hline & 1 & $0.50 \pm 0.05^{\mathrm{a}}$ & $0.59 \pm 0.02^{\mathrm{a}}$ & $0.39 \pm 0.03^{b}$ \\
\hline & 2 & $0.21 \pm 0.02^{b}$ & $0.19 \pm 0.02$ & $0.25 \pm 0.03$ \\
\hline \multirow{3}{*}{ 4-Isothiocyanato-1-butene } & 0 & $2.50 \pm 0.38^{b}$ & $2.96 \pm 0.19^{a}$ & $2.44 \pm 0.05^{b}$ \\
\hline & 1 & $0.57 \pm 0.01^{\mathrm{b}}$ & $0.78 \pm 0.00^{\mathrm{a}}$ & $0.48 \pm 0.00^{\mathrm{c}}$ \\
\hline & 2 & $0.05 \pm 0.01 \mathrm{NS}$ & $0.04 \pm 0.00$ & $0.06 \pm 0.00$ \\
\hline \multirow{3}{*}{ Acetic acid } & 0 & $0.12 \pm 0.02 \mathrm{NS}$ & $0.13 \pm 0.01$ & $0.09 \pm 0.01$ \\
\hline & 1 & $0.51 \pm 0.04^{\mathrm{a}}$ & $0.34 \pm 0.02^{c}$ & $0.42 \pm 0.03^{b}$ \\
\hline & 2 & $1.63 \pm 0.16^{\mathrm{a}}$ & $1.44 \pm 0.06^{b}$ & $1.78 \pm 0.02^{\mathrm{a}}$ \\
\hline \multirow{3}{*}{ Benzenepropanenitrile } & 0 & $0.75 \pm 0.13^{\mathrm{NS}}$ & $0.86 \pm 0.08$ & $0.88 \pm 0.02$ \\
\hline & 1 & $1.01 \pm 0.04^{\mathrm{a}}$ & $0.91 \pm 0.04^{\mathrm{a}}$ & $0.62 \pm 0.02^{b}$ \\
\hline & 2 & $1.04 \pm 0.08^{\mathrm{a}}$ & $0.76 \pm 0.06^{b}$ & $0.77 \pm 0.06^{b}$ \\
\hline \multirow{3}{*}{ Diallyl_disulphide } & 0 & $1.50 \pm 0.18^{\mathrm{NS}}$ & $1.44 \pm 0.09$ & $1.44 \pm 0.09$ \\
\hline & 1 & $3.95 \pm 0.28^{\mathrm{a}}$ & $2.82 \pm 0.16^{b}$ & $2.63 \pm 0.15^{c}$ \\
\hline & 2 & $3.68 \pm 0.50^{\mathrm{a}}$ & $3.17 \pm 0.25^{c}$ & $3.48 \pm 0.01^{b}$ \\
\hline \multirow{3}{*}{ Methyl-2-propenyl disulfide } & 0 & $0.95 \pm 0.16^{\mathrm{NS}}$ & $0.84 \pm 0.04$ & $0.97 \pm 0.05$ \\
\hline & 1 & $2.13 \pm 0.07^{\mathrm{a}}$ & $1.69 \pm 0.03^{b}$ & $1.33 \pm 0.04^{\mathrm{c}}$ \\
\hline & 2 & $1.20 \pm 0.15^{\mathrm{a}}$ & $0.76 \pm 0.09^{b}$ & $0.82 \pm 0.00^{b}$ \\
\hline \multirow{3}{*}{ Methyl-2-propenyl trisulfide } & 0 & $1.78 \pm 0.22^{\mathrm{NS}}$ & $1.46 \pm 0.12$ & $1.86 \pm 0.01$ \\
\hline & 1 & $1.26 \pm 0.10^{\mathrm{a}}$ & $0.96 \pm 0.04^{b}$ & $0.98 \pm 0.05^{b}$ \\
\hline & 2 & $1.07 \pm 0.15^{b}$ & $1.01 \pm 0.08^{b}$ & $1.16 \pm 0.04^{\mathrm{a}}$ \\
\hline \multirow{3}{*}{ Zingiberene } & 0 & $1.63 \pm 0.00^{\mathrm{a}}$ & $1.64 \pm 0.14^{\mathrm{a}}$ & $1.18 \pm 0.27^{\mathrm{b}}$ \\
\hline & 1 & $1.36 \pm 0.20^{\mathrm{a}}$ & $0.72 \pm 0.15^{b}$ & $0.62 \pm 0.06^{b}$ \\
\hline & 2 & $1.45 \pm 0.27^{\mathrm{a}}$ & $0.74 \pm 0.01^{\mathrm{c}}$ & $1.14 \pm 0.00^{b}$ \\
\hline
\end{tabular}

${ }^{1}$ All volatile compounds were identified by comparison with mass spectra and retention index database. Data are expressed as mean \pm SD. Different letters are significantly different among groups $(p<0.05)$, NS: not significant.

Furthermore, the contents of most of the volatile compounds in JA1 added kimchi were less than those in CON added kimchi. Methyl 2-propenyl trisulfide, a unique volatile component of raw garlic [32], was reduced by adding jeotgal alternatives on all weeks. Moreover, 3,7-dimethyl-2,6-octadienal, shown to impart a strong lemon flavor [33], was reduced with the addition of JA1 by approximately $30 \%$ compared to $\mathrm{CON}$ and rapidly decreased during kimchi fermentation. Unexpectedly, 4-isothiocyanato-1-butene content of kimchi with JA1 increased by $18 \%$ on weeks 0 and 1 compared to CON; however, it was hardly detected on week 2 . Though acetic acid and bezenepropanentrile contents were increased on weeks 1 and 2, they were lower than those in CON. The levels of most volatile compounds in JA2 added kimchi were similar to those in the CON, including 2-isothiocyanato-ethylbenzene, 4-isothiocyanato-1-butene, and methyl 2-propenyl trisulfide. Among volatile compounds, 4-Isothiocyanato-1-butene, (2-isothiocyanatoethyl)benzene, and 3,7-Dimethyl-2,6-octadien1-ol of JA1 are significantly decreased on week 0 . 4-isothiocyanato-1-butene is described as a gasoline-like flavor and isothiocynates are mainly described as the strong mustard-like pungent flavor. Hence, a significant reduction would be a positive effect of JA1. Overall, the findings revealed suggesting JA1 as a potential jeotgal alternative for kimchi application. 


\section{Conclusions}

In this study, soybean protein, beef, and tomato were used as potential sources for jeotgal alternatives. Initially, they were either extracted through hot water or enzymatically hydrolyzed using three different proteolytic enzymes (Alcalase, Protamex, and Flavourzyme). The findings revealed that glutamic acid content, the umami amino acid was higher in DBH, ISPA, and TH2 than the other preparation obtained from the same source. Profiling of the free amino acids and the volatile compounds in the above three preparation identified $\mathrm{DBH}$ and $\mathrm{TH} 2$ as potential alternatives to replace $\mathrm{CON}$. Subsequently, kimchi was prepared by adding either TH2 alone (JA1) or in combination with DBH (JA2). The addition of JA1 and JA2 showed a slow decrease in $\mathrm{pH}$ and low salinity compared to CON. In addition, JA1 and JA2 added kimchi showed higher glutamic acid contents than CON added kimchi, indicating the effects of JA1 and JA2 on the improved savory taste of kimchi. Futrthermore, JA1 and JA2 showed a similar or improved composition of volatile compounds compared with CON. Collectively, these findings suggest that JA1 containing $\mathrm{TH} 2$, a jeotgal alternative, could improve kimchi flavor and quality by reducing off-flavor and salinity.

Author Contributions: Conceptualization, Y.-R.Y.; methodology, Y.-R.Y., M.J.L., and Y.-J.C.; data curation, S.J.P., M.-A.L., and S.G.M.; writing-original draft preparation, review, and editing, H.J.L. and Y.-R.Y.; funding acquisition, Y.-R.Y., S.-H.P., and H.-Y.S.; supervision, Y.-R.Y. All authors have read and agreed to the published version of the manuscript.

Funding: This research was supported by the World Institute of Kimchi (KE1903-4-1 \& KE2002-22), funded by the Ministry of Sciences and ICT, and by the High Value-Added Food Technology Development Program (120024-02-1-CG000), funded by the Korea Institute of Planning \& Evaluation for Technology in Food, Agriculture, Forestry \& Fisheries, Republic of Korea.

Institutional Review Board Statement: Not applicable.

Informed Consent Statement: Not applicable.

Data Availability Statement: The data presented in this study are available in the article.

Conflicts of Interest: All authors declare no conflict of interest.

\section{References}

1. Koo, O.K.; Lee, S.J.; Chung, K.R.; Jang, D.J.; Yang, H.J.; Kwon, D.Y. Korean traditional fermented fish products: Jeotgal. J. Ethn. Foods 2016, 3, 107-116. [CrossRef]

2. Kim, J.S.; Kim, K.H. Processing and Characterization of Salt-Fermented Fish (Jeotgal) Using Seafood By-Products in Korea. Seafood Processing By-Products; Springer: New York, NY, USA, 2014; pp. 63-99.

3. Jung, M.Y.; Kim, T.W.; Lee, C.; Kim, J.Y.; Song, H.S.; Kim, Y.B.; Ahn, S.W.; Kim, J.S.; Roh, S.W.; Lee, S.H. Role of jeotgal, a Korean traditional fermented fish sauce, in microbial dynamics and metabolite profiles during kimchi fermentation. Food Chem. 2018, 265, 135-143. [CrossRef]

4. Ninomiya, K. Natural occurrence. Food Rev. Int. 1988, 14, 177-211. [CrossRef]

5. Fuke, S.; Konosu, S. Taste-active components in some foods: A review of Japanese research. Physiol. Behav. 1991, 49, 863-868. [CrossRef]

6. Park, K.Y.; Kwon, D.Y.; Lee, K.W.; Park, S. Korean Functional Foods: Composition, Processing and Health Benefits. Jeotgal (Fermented Fish); CRC Press: Boca Raton, FL, USA, 2018; pp. 183-209.

7. Zabat, M.A.; Sano, W.H.; Cabral, D.J.; Wurster, J.I.; Belenky, P. The impact of vegan production on the kimchi microbiome. Food Microbiol. 2018, 74, 171-178. [CrossRef] [PubMed]

8. Andayni, S.N.; Lioe, H.N.; Wijaya, C.H.; Ogawa, M. Umami fractions obtained from water-soluble extracts of red oncom and black oncom-Indonesian fermented soybean and peanut products. J. Food Sci. 2020, 85, 657-665. [CrossRef]

9. Zhu, X.; Sun-Waterhouse, D.; Chen, J.; Cui, C.; Wang, W. Comparative study on the novel umami-active peptides of the whole soybeans and the defatted soybeans fermented soy sauce. J. Sci. Food Agric. 2020, 101, 158-166. [CrossRef] [PubMed]

10. Skurray, G.R.; Pucar, N. L-glutamic acid content of fresh and processed foods. Food Chem. 1988, 27, 177-180. [CrossRef]

11. Al-Sayed, A.; Thomason, I. Meloidogyne incognita and tomato response to thiamine, ascorbic acid, L-arginine, and L-glutamic acid. J. Nematol. 1988, 20, 451-456.

12. Augusto, S.; Gisela, F.; Silvana, B.B.; Estela, M.V. Free amino acid production during tomato fruit ripening: A focus on L-glutamate. Amino Acids 2010, 38, 1523-1532. 
13. Kim, J.H.; Jeon, M.Y.; Lee, C.H. Physicochemical and sensory characteristics of commercial, frozen, dry, and wet-aged Hanwoo sirloins. Asian-Australas. J. Anim. Sci. 2019, 32, 1621-1629. [CrossRef] [PubMed]

14. Iida, F.; Miyazaki, Y.; Tsuyuki, R.; Kato, K.; Egusa, A.; Ogoshi, H.; Nishimura, T. Changes in taste compounds, breaking properties, and sensory attributes during dry aging of beef from Japanese black cattle. Meat Sci. 2016, 112, 46-51. [CrossRef]

15. AOAC. Official Method of Analysis, 15th ed.; Association of Official Analytical Chemist: Washington, DC, USA, 1975.

16. Valerio, F.; Conte, A.; Biase, M.D.; Lattanzio, V.M.T.; Lonigro, S.L.; Padalino, L.; Pontonio, D.; Lavermicocca, P. Formulation of yeast-leavened bread with reduced salt content by using a Lactobacillus plantarum fermentation product. Food Chem. 2017, 15, 582-589. [CrossRef] [PubMed]

17. Parker, J.K. Introduction to Aroma Compounds in Foods. In Flavour Development, Analysis and Perception in Food and Beverages; Woodhead Publishing: Cambridge, UK, 2015; pp. 3-30.

18. Zhang, H.; Huang, D.; Pu, D.; Zhang, Y.; Chen, H.; Sun, B.; Ren, F. Multivariate relationships among sensory attributes and volatile components in commercial dry porcini mushrooms (Boletus edulis). Food Res. Int. 2020, 133, 109112. [CrossRef]

19. Pongsetkul, J.; Benjakul, S.; Vongkamjan, K.; Sumpavapol, P.; Osako, K.; Faithong, N. Changes in volatile compounds, ATP-related compounds and antioxidative properties of Kapi, produced from Acetes vulgaris, during processing and fermentation. Food Biosci. 2017, 19, 49-56. [CrossRef]

20. Zhu, J.; Chen, F.; Wang, L.; Niu, Y.; Yu, D.; Shu, C.; Chen, H.; Wang, H.; Xiao, Z. Comparison of aroma-active volatiles in oolong tea infusions using GC-olfactometry, GC-FPD, and GC-MS. J. Agric. Food Chem. 2015, 63, 7499-7510. [CrossRef] [PubMed]

21. Xiao, D.R.; Liu, R.S.; He, L.; Li, H.M.; Tang, Y.L.; Liang, X.H.; Chen, T.; Tang, Y.J. Aroma improvement by repeated freeze-thaw treatment during Tuber melanosporum fermentation. Sci. Rep. 2015, 5, 17120. [CrossRef] [PubMed]

22. Vercammen, A.; Vivijs, B.; Lurquin, I.; Michiels, C.W. Germination and inactivation of Bacillus coagulans and Alicyclobacillus acidoterrestris spores by high hydrostatic pressure treatment in buffer and tomato sauce. Int. J. Food Microbiol. 2012, 152, 162-167. [CrossRef]

23. Lee, M.J.; Park, S.J.; Choi, Y.J.; Lee, M.A.; Yun, Y.R.; Min, S.G.; Seo, H.Y.; Her, J.Y.; Park, S.H. Evaluation of onion juices quality following heat-treatment and their application as a sugar substitute in Kimchi. J. Food Sci. Technol. 2020, 57, 4103-4110. [CrossRef] [PubMed]

24. Choi, Y.J.; Lee, H.W.; Yang, J.H.; Hong, S.W.; Park, S.H.; Lee, M.A. Changes in quality properties of Kimchi based on the nitrogen content of fermented anchovy sauce, myeolchi aekjeot, during fermentation. Food Sci. Biotechnol. 2018, 27, 1145-1155. [CrossRef] [PubMed]

25. Hawer, W.D.; Ha, J.H.; Seog, H.M.; Nam, Y.J.; Shin, D.W. Changes in the taste and flavour compounds of kimchi during fermentation. Korean J. Food Sci. Technol. 1988, 20, 511-517.

26. Rhee, S.J.; Lee, J.E.; Lee, C.H. Importance of lactic acid bacteria in Asian fermented foods. Microb. Cell Fact. 2011, 10, S5. [CrossRef]

27. Guo, Q.; Guo, L.; Wang, Z.; Zhuang, Y.; Gu, Z. Response surface optimization and identification of isothiocyanates produced from broccoli sprouts. Food Chem. 2013, 141, 1580-1586. [CrossRef] [PubMed]

28. Kang, J.H.; Lee, J.H.; Min, S.; Min, D.B. Changes of volatile compounds, lactic acid bacteria, pH, and headspace gases in Kimchi, a traditional Korean fermented vegetable product. J. Food Sci. 2003, 68, 849-854. [CrossRef]

29. Cha, Y.J.; Kim, H.; Cadwallader, K.R. Aroma-active compounds in kimchi during fermentation. J. Agric. Food Chem. 1998, 46, 1944-1953. [CrossRef]

30. Hong, S.P.; Lee, E.J.; Kim, Y.H.; Ahn, D.U. Effect of fermentation temperature on the volatile composition of kimchi. J. Food Sci. 2016, 81, 2623-2629. [CrossRef] [PubMed]

31. Kim, M.N.; Lee, M.A.; Lee, K.G. Determination of compositional quality and volatile flavor characteristics of radish-based Kimchi suitable for Chinese consumers and its correlation to consumer acceptability. Food Sci. Biotechnol. 2018, 27, 1265-1273. [CrossRef] [PubMed]

32. Keleş, D.; Taşkin, H.; Baktemur, G.; Kafkas, E.; Büyükalaca, S. Comparitive study on volatile aroma compounds of two different garlic types (Kastamonu and Chinese) using gas chromatography mass spectrometry (HS-GC/MS) technique. Afr. J. Tradit. Complement. Altern. Med. 2014, 11, 217-220. [CrossRef]

33. Shahzadi, P.; Muhammad, A.; Mehmood, F.; Chaudhry, M. Synthesis of 3, 7-dimethyl-2, 6-octadienal acetals from citral extracted from lemon grass, Cymbopogon citrates L. J. Antivir. Antiretrovir. 2014, 6, 28-31. [CrossRef] 